An empirical study on the motivations underlying augmented reality game use:

The case of Pokémon Go during and after Pokémon fever

Ágnes Zsila ${ }^{1,2, \dagger}$, Gábor Orosz ${ }^{2,3, \dagger, *}$, Beáta Bőthe ${ }^{1,2}$, István Tóth-Király ${ }^{1,2}$,Orsolya Király², Mark Griffiths $^{4}$, Zsolt Demetrovics ${ }^{2}$

${ }^{1}$ Doctoral School of Psychology, Eötvös Loránd University, Budapest, Hungary

${ }^{2}$ Institute of Psychology, Eötvös Loránd University, Budapest, Hungary

${ }^{3}$ Institute of Cognitive Neuroscience and Psychology, Hungarian Research Centre for Natural Sciences, Budapest, Hungary

${ }^{4}$ Nottingham Trent University, Psychology Department, Nottingham, United Kingdom †Ágnes Zsila and Gábor Orosz contributed equally to this work and their order was determined at random. Both should be considered first authors.

*Corresponding author

Dr. Gábor Orosz

Institute of Psychology, Eötvös Loránd University

Izabella utca 46., Budapest, H-1064, Hungary

E-mail: gaborosz@gmail.com

Tel.: 0036702379471

Funding sources: The study was supported by the Hungarian National Research, Development and Innovation Office (Grant numbers: PD106027, PD116686, K111938), the Hungarian Academy of Sciences (Lendület Project LP2012-36), and the ÚNKP-16-3 New National Excellence Program of the Ministry of Human Capacities.

Conflict of interest: The authors declare no conflict of interest. 


\title{
An empirical study on the motivations underlying augmented reality games: The case of Pokémon Go during and after Pokémon fever
}

\section{Highlights}

Through two studies we identified 10 motivational factors of Pokémon Go use.

The factor structure of this measure was stable during and after Pokémon fever.

Three game-specific motivations were: Outdoor Activity, Nostalgia, and Boredom.

Impulsivity was unrelated to Pokémon-Go motives.

Competition and fantasy motivations predicted problematic gaming behavior.

\begin{abstract}
In 2016, Pokémon Go became the most popular game in the history of smartphone games and was among the first games to feature geo-located augmented reality (AR) elements. The goal of the present research was to obtain a deeper understanding concerning the motivations underlying Pokémon Go use and to create a measure that assesses these motivations. By extending the framework of the Motives for Online Gaming Questionnaire, three new factors Outdoor Activity, Nostalgia, and Boredom - were added based on the findings of qualitative analysis, and which led to the creation of the Motives for Online Gaming Questionnaire Pokémon Go extension (MOGQ-PG). Confirmatory factor analysis was carried out on a sample of Pokémon Go players ( $\mathrm{N}=621$ ). Results demonstrated that the final 37-item, first-order, 10 factor model had appropriate factor structure and internal consistency. A second follow-up study on Pokémon Go players ( $\mathrm{N}=510)$ examined associations between gaming motivations, problematic use, and impulsivity. Results demonstrated that impulsivity was not related to the MOGQ-PG motives. Results also showed that competition and fantasy motivations predicted problematic gaming behavior. The present research is the first empirical contribution to the
\end{abstract}


assessment and understanding of the motivational background of playing AR games such as Pokémon Go.

Keywords: Augmented reality games; Confirmatory factor analysis (CFA); Gaming motivation; MOGQ-PG; Pokémon Go; Psychometric scale development 


\section{Introduction}

\subsection{The Pokémon Go phenomenon}

Over the last 15 years, most videogames have traditionally been played online or offline. Recently, new forms of games (most notably Pokémon Go), implementing augmented reality, have become popular worldwide. Over 100 million users from 30 countries downloaded Pokémon Go within a few weeks, and were reported to be playing it for 26 minutes in an average day (Smith, 2016). Considering the unparalleled popularity of this new game, the popular media has asked what the key motivations are behind playing this game (Griffiths, 2016). The primary goal of the present study was to identify the motivational factors that explain this new playing phenomenon. In order to achieve this goal, the pre-existing theoretical framework of online motivational literature was extended (Demetrovics et al., 2011) with new motives that appeared to be relevant in the playing and popularity of augmented reality games.

In recent years, smartphones became more advanced with the inclusion of a built-in camera, GPS for navigation, and Internet connectivity (Chou \& ChanLin, 2012). This technological evolution facilitated the emergence of augmented reality (AR) technology. AR mixes the real and the virtual world by creating a user-centered environment, where the real world is augmented or complemented with computer-generated elements (such as graphical objects), leading to a deeper immersion (Baranowski, 2016; Chou \& ChanLin, 2012; Graham, Zook, \& Boulton, 2012). This technology has already been employed in campus and library touring (e.g., Chou \& ChanLin, 2012; Hahn, 2013), tourism (Yovcheva, Buhalis, \& Gatzidis, 2012), education and learning (e.g., Dunleavy \& Dede, 2014; Wu, Lee, Chang, \& Liang, 2013), and more recently, gaming.

As noted above, arguably one the most popular augmented reality games at present is Pokémon Go. The Pokémon franchise was originally created by a Japanese videogame designer, Satoshi Tajiri. In the mid-1990s, Tajiri developed videogames for Nintendo’s Game 
Boy devices, introducing the world of 'Pocket Monsters', in which the players are instructed to collect all the Pokémon species they find in virtual cities. In the early 2000s, the story of Pokémon videogames was adapted into an anime series, and which also became increasingly popular outside Japan (Soromjai, 2000). Ever since the adventures of Ash Ketchum (an ambitious Pokémon Master of the animated series) attracted many young viewers, the Pokémon franchise has expanded rapidly. As a result, movies, comics, trading cards, toys, and other productions were manufactured as part of the “Gotta Catch 'Em All” global media sensation. The latest wave of this phenomenon was initiated by The Pokémon Company in the summer of 2016, when Pokémon Go was introduced to millions of smartphone users.

In this game, the user creates an avatar and then chooses a team to fight with. The game takes into consideration the user's geographical location and by moving around in real world surroundings, the player can find and capture "wild” Pokémon. Furthermore, while on the move, the player can find other resources that can be useful in developing the captured Pokémon species. For instance, one can find eggs containing Pokémon that will hatch over time, and different items that can help in capturing them. Players can participate in battles in which they can improve their skills by challenging other players who have control over the Pokémon gym (i.e., the battle arena). The main purpose of the game is to collect all the Pokémon species and improve their abilities.

\subsection{The motivational background of playing Pokémon Go}

Despite the fact that research regarding AR gaming motivation has a relatively short history (as indicated by Baranowski, 2016), the comprehensive theoretical model of online gaming motivations posited by Demetrovics et al. (2011) was considered by the present authors to be the most appropriate approach to assess the motivation of playing AR games such as Pokémon Go. Motivation can be defined as "the process of starting, directing and maintaining 
physical and psychological activities; includes mechanisms involved in preferences for one activity over another and the vigour and persistence of responses” (Gerrig, Zimbardo, Campbell, Cumming, \& Wilkes, 2010, p. 409).

In the present study, consideration of previous research examining online gaming motivations that have a strong inductive (empirical) or deductive (theoretical) background and good psychometric properties were taken into account. The basis of the present assessment was the Motives for Online Gaming Questionnaire (MOGQ; Demetrovics et al., 2011) which includes seven motivational factors for playing online games. The Social dimension of the MOGQ reflects on the motivation of playing with others, and sharing the experiences. Escapism contains items focusing on the escapist motivation of players to dissociate themselves from reality and real-life problems. The Competition dimension represents the motivation to defeat others and win. The Coping dimension comprises items emphasizing the role of games in coping with distress and getting into a better mood. Skill Development refers to motives of improving coordination, concentration, and other cognitive skills. Fantasy refers to the motives of stepping outside the boundaries of the real world. Finally, the three items of the Recreation factor emphasize the entertaining and relaxing aspects of gaming.

\subsection{Pokémon Go playing motivations, impulsivity, and problematic gaming}

To the best of the authors' knowledge, very little prior research has focused on the role of impulsivity in problematic gaming (e.g., Liau et al., 2015; Metcalf \& Pammer, 2014; Nuyens et al., 2016). However, in the existing literature, a diverse conceptualization of impulsivity exists (e.g., Patton, Stanford, \& Barratt, 1995; Mischel, Shoda, \& Rodriguez, 1989; see also Whiteside \& Lynam, 2001). Whiteside and Lynam (2001) developed the multidimensional UPPS Impulsive Behavior Scale in order to examine the multifaceted concept of impulsivity. 
According to Whiteside et al. (2005), impulsivity refers to feeling pressured to engage in a behavior or feeling like having to give in to it.

Impulsivity appears to be a risk factor for engaging in maladaptive, deviant, and problematic behaviors. For instance, positive correlations have been found between dimensions of impulsivity and problematic online behaviors such as problematic internet use (Burnay, Billieux, Blairy, \& Larøi, 2015; Mottram \& Fleming, 2009). Within online-related activities, problematic gaming has been found to be positively related to impulsivity (Liau et al., 2015; Metcalf \& Pammer, 2014; Nuyens et al., 2016). However, no prior studies have examined how gaming motivations are related to impulsivity. Thepresent study attempted to identify which motivational aspects of playing Pokémon Go are related to impulsivity. Based on the association between gaming motivations and problematic gaming (Király et al., 2015), as well as considering the previously explored links between impulsivity and problematic gaming (Liau et al., 2015; Metcalf \& Pammer, 2014; Nuyens et al., 2016), it was expected that specific motivational variables would be related to impulsivity that were found to be predictors of problematic gaming (i.e., escapism and competition).

\subsection{The aims of the study}

Building on the motivational framework of the MOGQ (Demetrovics et al., 2011), the aim of the present research was to explore the motivational background of playing Pokémon Go. More specifically, Study 1 explored whether there are additional motivational factors underlying the playing of Pokémon Go, whereas Study 2 investigated the associations between the motivational factors, problematic gaming, and different aspects of impulsivity as personality-related variables.

\section{Study 1}


The aim of the first study was to create a short assessment instrument to assess Pokémon Go playing motivations. The construction of relevant factors was considered on the basis of prior findings regarding the motivational background of playing online games (Demetrovics et al., 2011). Furthermore, qualitative research was conducted to explore possible additional motives for playing Pokémon Go.

\subsection{Methods}

\subsubsection{Item Construction}

The aim of the present study was to identify possible additional motives of gaming motivations specific to Pokémon Go (compared to the original MOGQ motives). To attain this, a qualitative exploration was performed on a sample of 37 participants (35.14\% female; $M_{a g e}=$ 22.03 years, $S D=5.10$ ) who were regular players of Pokémon Go. The participants were recruited from a Hungarian Pokémon Go-themed online community that had more than 2,000 members. The administrator advertised the call for participation. Using an online questionnaire, participants were invited to complete the following sentence: “I play Pokémon Go because...”. A total of 117 motivations were collected, of which 114 were considered as the basis for the creation of new motivational factors (those omitted were the ones that did not make any sense to the research team).

Following this, three expert raters independently selected responses that could not be categorized into any of the original seven motivational dimensions of the MOGQ (27.35\% of the responses). All raters were psychologists with prior experience in the field of motivation research and qualitative methods. If consensus could not be achieved regarding the classification of a response statement, raters were then allowed to discuss the statement (5\% of the responses). Based on the motivational factors identified in previous online gaming literature 
(Demetrovics et al., 2011), responses that did not reflect any of the original MOGQ motivational dimensions (31 responses) were coded to form three new categories on the basis of content analysis: Outdoor Activity (13 responses which emphasized that Pokémon Go encourages players to walk out of their rooms and breathe some fresh air), Nostalgia (seven responses which referred to the experience of viewing the anime series entitled 'Pokémon' in the early 2000s, and wishing to revive old memories), and Boredom (11 responses which referred to the motive of passing time playing when there is nothing else to do). After the exclusion of duplicates (i.e., matching content), 15 Pokémon Go-specific items (five per factor) remained that were rephrased by the research team to conceptually reflect the respective factor in a wide variety of different ways, and were added to the original 27 items of the MOGQ.

\subsubsection{Participants and procedure}

A total of 1068 participants completed the online survey. In the analysis, individuals who did not provide an informed consent $(n=104)$ were excluded, along with responses $(i)$ that had severe inconsistencies ( $\mathrm{n}=1$ ), (ii) by under-aged participants ( $\mathrm{n}=45$ ), and (iii) that indicated they had not played Pokémon Go $(\mathrm{n}=297)$. Therefore, the final sample comprised 621 participants aged between 18 and 54 years $\left(M_{\text {age }}=22.57\right.$ years, $\left.S D=4.37\right)$.

The average amount of time spent playing Pokémon Go was 10.42 hours during the week preceding the data collection $(S D=12.22)$. Nearly half of the participants $(n=303)$ played Pokémon Go daily on their mobile phones (48.79\%), whereas 240 played 2-6 times per week (38.63\%), and 78 played only weekly or rarely. Only 14 participants reported to play on other platforms than their mobile phones (2.25\%). A multiple-choice question (in which participants could endorse more than one category) revealed that the majority of participants $(n=382)$ played Pokémon Go alone (61.51\%), whereas some individuals played with their friends 
(55.87\%), partner (32.36\%), random people who played Pokémon Go at the same place (24.32\%), brothers or sisters (22.71\%), and parents (4.51\%).

The study was carried out with the approval of the Institutional Review Board of the research team's university and performed in accordance with the Declaration of Helsinki. Participants were recruited from the largest Hungarian communities on social networking sites that thematically focused on online games $(n=3)$ and anime $(n=4)$ in July 2016 when the popularity of Pokémon Go use was at its peak in Hungary. Two of the anime communities comprised about 200 members, whereas the other five groups had 2,000-8,000 members. Since the Pokémon franchise gained much attention in the early 2000s in Hungary, the present authors considered that anime enthusiasts who were fans of the Pokémon anime series would also be affected in the Pokémon Go phenomenon. Before completing an online survey, participants were informed about the aims of the study and were asked to provide informed consent by ticking a box if they were over 18 years and agreed to the terms of the study. The participation in the survey was voluntary and anonymous.

\subsubsection{Measures}

2.1.3.1. Pokémon Go-specific variables. The Pokémon Go playing activity (i.e., time spent playing, platform, social connectedness) of the participants were recorded. Furthermore, two questions assessed participants’ attitude and exposure to Pokémon anime. First, participants were asked to indicate the frequency of viewing Pokémon prior to the introduction of Pokémon Go ( 1 = never, 2 = rarely, 3 = some of the time, 4 = often, 5 = very often $)$. Second, they were asked how much they liked Pokémon prior to the introduction of Pokémon Go ( 1 = I did not like it at all, 2 = I rather disliked it, $3=\mathrm{I}$ was neutral, $4=\mathrm{I}$ rather liked it, $5=\mathrm{I}$ liked it very much). For further analysis, players were separated into two categories based on their previous experiences with Pokémon. Players who reported a high frequency of viewing Pokémon anime 
prior to the introduction of Pokémon Go (often or very often) and exhibited the most positive attitudes toward it (indicated by the highest degree of liking) were categorized as old Pokémon fans ( $\mathrm{n}=351)$, whereas players who had only sometimes, rarely or never viewed Pokémon prior to the introduction of Pokémon Go and indicated a relatively low degree of liking (e.g., 'I was neutral', 'I did not like it at all') were categorized as new Pokémon fans ( $\mathrm{n}=270)$.

\subsubsection{Motives for Online Gaming Questionnaire - Pokémon Go extension (MOGQ-} $P G)$. Gaming motives were assessed using the 27-item MOGQ and the 15 new items that were created for the purpose of this research. The MOGQ was adapted for Pokémon Go playing by changing “online games” to "Pokémon Go" in the instructions. The original seven motivational factors were the following: Social (four items; e.g., "because I can meet many different people”), Escape (four items; e.g., "because gaming helps me to forget about daily hassles”), Competition (four items; e.g., "because I enjoy competing with others”), Coping (four items; e.g., "because it helps me get rid of stress”), Skill development (four items; e.g., "because it improves my skills”), Fantasy (four items; e.g., "because I can be in another world”), and Recreation (three items; e.g., "because it is entertaining”). Respondents indicated the frequency of motives on a five-point Likert scale (ranging from 1 = 'almost never/never' to $5=$ 'almost always/always').

\subsubsection{Statistical analysis}

Confirmatory factor analysis (CFA) was performed to assess the psychometric properties of this new measure that integrated the original and the additional gaming motivation dimensions. For this analysis, Mplus 7.3 was used (Muthén \& Muthén, 1998-2015) with the weighted least squares mean- and variance-adjusted (WLSMV) estimator.

\subsection{Results}




\subsubsection{Confirmatory factor analysis - Creation of the Motives for Online Gaming Questionnaire}

\section{- Pokémon Go extension (MOGQ-PG)}

Before testing the 10-factor structure of the MOGQ-PG, further item selection was performed based on methodological considerations. After the first item selection, which was based on the content of qualitative responses, the research team limited the number of items in each factor in order to construct a short tool for assessing Pokémon Go playing motives. Given that four items can adequately define a latent construct (similar to that of Demetrovics et al., 2011), a maximum of four items in each factor was determined as the upper limit. In order to preserve the content validity of the subscales, the item selection was performed focusing on both the factor loadings and the content of the items. Here, the aim was-by using the qualitative statements - to select those items that conceptually represented the content of the factors in a wide variety, and strongly loaded on their respective factors. Subsequently, two items were excluded from the Boredom and the Nostalgia factors due to the relatively low itemtotal correlations. Regarding the Outdoor Activity factor, four items were selected that reflect on the two aspects of this motivation, namely playing to become healthier by walking and playing to spend time in the nature. This final solution resulted in 37 items and 10 factors and was examined with CFA to test its appropriateness.

This final model (see Table 1 ) indicated an adequate fit to the data $\left(\chi^{2}=1755.421\right.$; degrees of freedom $=584 ; \mathrm{p}<.001 ; \mathrm{CFI}=.963 ; \mathrm{TLI}=.958 ;$ RMSEA $=.057[.054-.060])$. All factor loadings were high $(\lambda=.68$ to .95$)$, while inter-factor correlations were moderate $(r=.26$ to .84$)$. Cronbach's alpha values were also good ( $\alpha=.77$ to .92$)$. According to these results, the final 10-factor model demonstrated an adequate fit and internal consistency, reflecting the structural construct of the theoretical model. The final, 37-item list comprises all 27 MOGQitems, and 10 items of the three new, Pokémon Go-specific factors. A second study investigated the relationships between the motivational factors, problematic gaming, and impulsivity. 
Table 1

Parameter estimates, descriptive statistics and reliability indices for the Online Gaming Questionnaire-Pokémon Go extension (MOGQ-PG) on Sample $1(N=621)$

\begin{tabular}{|c|c|c|c|c|c|}
\hline \multirow{2}{*}{ I play Pokémon Go... } & \multirow[b]{2}{*}{$\alpha$} & \multicolumn{3}{|c|}{ Descriptive statistics } & \multirow{2}{*}{$\begin{array}{l}\text { Factor } \\
\text { loadings }\end{array}$} \\
\hline & & Range & Mean & $\mathrm{SD}$ & \\
\hline Social & .89 & $1-5$ & 2.34 & 1.11 & \\
\hline 1. ... because I can get to know new people & & & & & .90 \\
\hline 10. ... because I can meet many different people & & & & & .94 \\
\hline 21. ... because it is a good social experience & & & & & .82 \\
\hline 32. ... because gaming gives me company & & & & & .90 \\
\hline
\end{tabular}

\begin{tabular}{lllll}
\hline Escape & .85 & $1-5$ & 2.02 & 1.06
\end{tabular}

2. ... because gaming helps me to forget about daily hassles

12. ... because it makes me forget real life .86

22. ... because gaming helps me escape reality .93

33. ... to forget about unpleasant things or offences .84

Competition .92 $1-5$

$2.45 \quad 1.24$

4. ... because I enjoy competing with others .85

13. ... because I like to win

23. ... because it is good to feel that I am better than others

34. ... for the pleasure of defeating others

Coping .80 $1-5$ 2.27 0.96

6 . ... because gaming helps me get into a better mood

15. ... because it helps me get rid of stress .83

25. ... because it helps me channel my aggression .78

35. ... because it reduces tension .85

Skill development .87 $1-5$ 1.95 0.95

7. ... because gaming sharpens my senses .79

17. ... because it improves my skills .88

26. ... because it improves my concentration .88

36 . ... because it improves my coordination skills 
8. ... because I can do things that I am unable to do or I am not allowed to do in real life

18. ... to feel as if I was somebody else $\quad .86$

28. ... to be somebody else for a while $\quad .94$

37. ... because I can be in another world 89

\begin{tabular}{lllll}
\hline Recreation & .77 & $1-5$ & 4.00 & 0.87
\end{tabular}

9. ... for recreation $\quad$.77

19. ... because it is entertaining $\quad .81$

30. ... because I enjoy gaming $\quad$ 89

\begin{tabular}{lllll}
\hline Outdoor activity & .92 & $1-5$ & 3.00 & 1.24
\end{tabular}

11. ... because it gets me moving $\quad .89$

24. ... because I spend more time in the fresh air $\quad .86$

29. ... because it provides the daily dose of exercise $\quad .90$

31. ... because I can get out of the house $\quad .92$

$\begin{array}{lllll}\text { Nostalgia } & .92 & 1-5 & 3.57 & 1.32\end{array}$

5. ... because it reminds me of my childhood $\quad .94$

16. ... it is nostalgic $\quad .94$

27. ... it brings up old memories $\quad .89$

\begin{tabular}{lllll}
\hline Boredom & .78 & $1-5$ & 2.80 & 1.12
\end{tabular}

3. ... at least I am not bored meanwhile $\quad .79$

14. ... otherwise I would be bored $\quad .94$

20. ... time goes faster $\quad .89$

Note. $\alpha=$ Cronbach's alpha value; $\mathrm{SD}=$ standard deviation. The instruction was the following:

People play Pokémon Go for different reasons. Some reasons are listed below. Please indicate how often you play Pokémon Go for the reasons listed below by clicking on the appropriate response - almost never/never (1), some of time (2), half of the time (3), most of the time (4), almost always/always (5). There is no right or wrong answer! We are only interested in your motives for playing.

\subsubsection{Associations between Pokémon Go playing motives and demographic characteristics}

The highest mean scores were found in the Recreation and Nostalgia motives, whereas the lowest scores were observed in Escape and Skill Development motives (see Table 2). Only one motive (Recreation) had higher scores than the three new motivational factors. There were significant mean differences across gender on the Social $t(562)=3.97, p<.001$ and 
Competition motives, $t(557)=4.83, p<.001$ with men having significantly higher scores than women. Men also reported to play Pokémon Go more frequently than women $t(593)=3.06, p$ $=.002$. Regarding residence, it was found that players who lived in county towns, other towns and villages yielded higher scores on the Skill Development $(F(620)=2.66, p=.05)$ and Boredom $(F(620)=3.21, p=0.02)$ motives than those who lived in the capital city. Participants with higher educational levels played less and showed lower motivational levels in the majority on the MOGQ-PG motivational dimensions, except for the Recreation, Outdoor Activity and Nostalgia. In line with this result, weak but significant associations showed between age and the Social, Escape, Competition, Coping, Fantasy, Nostalgia, and Boredom motives (the strength of correlations were between -0.10 and $-0.23, p<0.05$ ). Finally, those who had been fans of Pokémon anime prior to the introduction of Pokémon Go (Old Pokémon Fans), played more and scored higher on all motivational factors except for the Competition motive, in which the mean score-difference between Old Pokémon Fans and New Pokémon Fans was not statistically significant. The greatest difference in the mean scores of these two groups was observed in the Nostalgia motivation (Mold Pokémon Fans $=4.21, S D=0.94 ; M_{\text {New }}$ Pokémon Fans $=2.74$, $S D=1.29)$.

Table 2

Descriptive statistics and group comparisons in Sample $1(N=621)$

\begin{tabular}{|c|c|c|c|c|c|c|c|c|c|c|}
\hline & & $\mathrm{Ge}$ & nder & & & Resi & lence & & & \\
\hline & $\begin{array}{l}\text { Total } \\
(\mathrm{N}=621)\end{array}$ & $\begin{array}{l}\text { Male } \\
(n=280)\end{array}$ & $\begin{array}{l}\text { Female } \\
(\mathrm{n}=341)\end{array}$ & $t$ & $\begin{array}{l}\text { Capital } \\
\text { city } \\
(\mathrm{n}=171)\end{array}$ & $\begin{array}{l}\text { County } \\
\text { towns } \\
(\mathrm{n}=72)\end{array}$ & $\begin{array}{l}\text { Other } \\
\text { towns } \\
(\mathrm{n}=274)\end{array}$ & $\begin{array}{l}\text { Villages } \\
(\mathrm{n}=104)\end{array}$ & $F$ & \\
\hline $\begin{array}{l}\text { Frequency of } \\
\text { playing }\end{array}$ & $\begin{array}{l}10.42 \\
(12.22)\end{array}$ & $\begin{array}{l}12.07 \\
(12.16)\end{array}$ & $\begin{array}{l}9.07 \\
(12.12)\end{array}$ & $3.06^{* *}$ & $\begin{array}{l}10.95 \\
(12.25) \mathrm{a}\end{array}$ & $\begin{array}{l}8.32 \\
(8.11) \mathrm{a}\end{array}$ & $\begin{array}{l}11.03 \\
(13.34) \mathrm{a}\end{array}$ & $\begin{array}{l}9.42 \\
(11.39) a\end{array}$ & 1.27 & 8. \\
\hline Social & $\begin{array}{l}2.34 \\
(1.11)\end{array}$ & $\begin{array}{l}2.53 \\
(1.17)\end{array}$ & $\begin{array}{l}2.18 \\
(1.03)\end{array}$ & $3.97^{* * *}$ & $\begin{array}{l}2.28 \\
(1.08) \mathrm{a}\end{array}$ & $\begin{array}{l}2.52 \\
(1.05) \mathrm{a}\end{array}$ & $\begin{array}{l}2.33 \\
(1.11) \mathrm{a}\end{array}$ & $\begin{array}{l}2.33 \\
81.19) \mathrm{a}\end{array}$ & 0.86 & $\begin{array}{l}2 . \\
(1\end{array}$ \\
\hline
\end{tabular}




\begin{tabular}{|c|c|c|c|c|c|c|c|c|c|}
\hline Escape & $\begin{array}{l}2.02 \\
(1.06)\end{array}$ & $\begin{array}{l}1.95 \\
(1.10)\end{array}$ & $\begin{array}{l}2.08 \\
(1.03)\end{array}$ & -1.56 & $\begin{array}{l}1.91 \\
(0.97) \mathrm{a}\end{array}$ & $\begin{array}{l}2.04 \\
(1.01) \mathrm{a}\end{array}$ & $\begin{array}{l}2.08 \\
(1.12) \mathrm{a}\end{array}$ & $\begin{array}{l}2.03 \\
(1.07) \mathrm{a}\end{array}$ & 0.94 \\
\hline Competition & $\begin{array}{l}2.45 \\
(1.24)\end{array}$ & $\begin{array}{l}2.71 \\
(1.30)\end{array}$ & $\begin{array}{l}2.23 \\
(1.13)\end{array}$ & $4.83^{* * *}$ & $\begin{array}{l}2.37 \\
(1.22) \mathrm{a}\end{array}$ & $\begin{array}{l}2.36 \\
(1.23) a\end{array}$ & $\begin{array}{l}2.51 \\
\text { (1.28)a }\end{array}$ & $\begin{array}{l}2.48 \\
(1.15) \mathrm{a}\end{array}$ & 0.54 \\
\hline Coping & $\begin{array}{l}2.27 \\
(0.96)\end{array}$ & $\begin{array}{l}2.23 \\
(0.97)\end{array}$ & $\begin{array}{l}2.30 \\
(0.95)\end{array}$ & -0.80 & $\begin{array}{l}2.14 \\
(0.89) \mathrm{a}\end{array}$ & $\begin{array}{l}2.24 \\
(0.81) a\end{array}$ & $\begin{array}{l}2.32 \\
(1.03) \mathrm{a}\end{array}$ & $\begin{array}{l}2.35 \\
(0.99) \mathrm{a}\end{array}$ & 1.54 \\
\hline Skill Development & $\begin{array}{l}1.95 \\
(0.95)\end{array}$ & $\begin{array}{l}1.92 \\
(0.96)\end{array}$ & $\begin{array}{l}1.98 \\
(0.95)\end{array}$ & -0.74 & $\begin{array}{l}1.79 \\
(0.89) \mathrm{a}\end{array}$ & $\begin{array}{l}1.99 \\
(0.90) \mathrm{b}\end{array}$ & $\begin{array}{l}1.99 \\
(0.98) b\end{array}$ & $\begin{array}{l}2.09 \\
(0.99) \mathrm{b}\end{array}$ & $2.66^{*}$ \\
\hline Fantasy & $\begin{array}{l}2.23 \\
(1.16)\end{array}$ & $\begin{array}{l}2.20 \\
(1.15)\end{array}$ & $\begin{array}{l}2.25 \\
(1.16)\end{array}$ & -0.53 & $\begin{array}{l}2.06 \\
(1.09) \mathrm{a}\end{array}$ & $\begin{array}{l}2.21 \\
(1.15) \mathrm{a}\end{array}$ & $\begin{array}{l}2.29 \\
(1.18) \mathrm{a}\end{array}$ & $\begin{array}{l}2.38 \\
(1.18) a\end{array}$ & 2.04 \\
\hline Recreation & $\begin{array}{l}4.00 \\
(0.87)\end{array}$ & $\begin{array}{l}3.93 \\
(0.89)\end{array}$ & $\begin{array}{l}4.06 \\
(0.85)\end{array}$ & -1.79 & $\begin{array}{l}4.02 \\
(0.87) \mathrm{a}\end{array}$ & $\begin{array}{l}4.08 \\
(0.71) a\end{array}$ & $\begin{array}{l}3.96 \\
(0.92) a\end{array}$ & $\begin{array}{l}4.02 \\
(0.86) \mathrm{a}\end{array}$ & 0.44 \\
\hline Outdoor Activity & $\begin{array}{l}3.00 \\
(1.24)\end{array}$ & $\begin{array}{l}2.90 \\
(1.24)\end{array}$ & $\begin{array}{l}3.08 \\
(1.24)\end{array}$ & -1.83 & $\begin{array}{l}2.89 \\
(1.22) \mathrm{a}\end{array}$ & $\begin{array}{l}3.19 \\
(1.13) a\end{array}$ & $\begin{array}{l}3.00 \\
(1.27) \mathrm{a}\end{array}$ & $\begin{array}{l}3.04 \\
(1.27) \mathrm{a}\end{array}$ & 1.09 \\
\hline Nostalgia & $\begin{array}{l}3.57 \\
(1.32)\end{array}$ & $\begin{array}{l}3.53 \\
(1.30)\end{array}$ & $\begin{array}{l}3.61 \\
(1.33)\end{array}$ & -0.81 & $\begin{array}{l}3.43 \\
(1.40) \mathrm{a}\end{array}$ & $\begin{array}{l}3.74 \\
(1.26) a\end{array}$ & $\begin{array}{l}3.58 \\
(1.29) \mathrm{a}\end{array}$ & $\begin{array}{l}3.68 \\
(1.28) \mathrm{a}\end{array}$ & 1.23 \\
\hline Boredom & $\begin{array}{l}2.80 \\
(1.12)\end{array}$ & $\begin{array}{l}2.76 \\
(1.19)\end{array}$ & $\begin{array}{l}2.83 \\
(1.06)\end{array}$ & -0.78 & $\begin{array}{l}2.66 \\
(1.04) \mathrm{a}\end{array}$ & $\begin{array}{l}2.88 \\
(1.11) b\end{array}$ & $\begin{array}{l}2.77 \\
(1.16) \mathrm{b}\end{array}$ & $\begin{array}{l}3.08 \\
(1.12) \mathrm{b}\end{array}$ & $3.21^{*}$ \\
\hline
\end{tabular}

Notes. $^{*} \mathrm{p}<.05 ;^{* *} \mathrm{p}<.01 ;{ }^{* * *} \mathrm{p}<.001$

Different subscript letters (a, b, c) in the same row represent significant $(p<.05)$ difference between the mean scores, whereas same subscript letters in the same row represent nonsignificant difference between the mean scores according to the post-hoc Tukey test of oneway ANOVA.

\section{Study 2}

\subsection{Introduction}

The aim of the second study was to explore the associations between Pokémon Go playing motivations, impulsivity, and problematic gaming. The associations between online gaming motivations and problematic online gaming, and the relationships between impulsivity and problematic online gaming have already been explored separately (Király et al., 2015; Liau et al., 2015; Metcalf \& Pammer, 2014; Nuyens et al., 2016). However, no prior studies have examined impulsivity, motivations, and problematic gaming simultaneously. Therefore, the 
second aim of the present study was to test an integrated regression model including impulsivity as a personality-related predictor, andthe motivations of playing Pokémon Go as a more proximal predictor of problematic Pokémon Go playing.

\subsection{Methods}

\subsubsection{Participants and Procedure}

Data was gathered in the same online groups as that in Study 1 in November 2016, after the peak Pokémon Go’s popularity had subsided in Hungary. In the present study, after reading the informed consent and agreeing to participate, respondents were first presented with demographic and Pokémon Go-specific questions, followed by scales assessing gaming motivations, problematic use, and impulsivity.

A total of 510 Hungarian participants (females $=225,44.12 \%$ ) participated in the research. Participants were aged between 18 and 63 years $\left(M_{\text {age }}=26.64, S D_{\text {age }}=7.80\right)$. All of them were active Pokémon Go players at the time of the study (see the frequency of gaming in Table 3).

\subsubsection{Measures}

3.2.2.1. MOGQ-PG. The same measure-with 37 items and 10 factors-was administered as in Study 1.

\subsubsection{Problematic Online Gaming Questionnaire - Short Form (POGQ-SF).} Problematic Pokémon Go playing was assessed with the 12-item version of the POGQ (Demetrovics et al., 2012), assessing the six components of problematic gaming (i.e., preoccupation, immersion, withdrawal, overuse, interpersonal conflicts, and social isolation) on the basis of both empirical and theoretical content. For the purpose of the present study, the items were adapted specifically to assess the problematic use of Pokémon Go (e.g., How often 
do you neglect other activities because you would rather play Pokémon Go?” Participants were asked to answer on a five-point scale ( 1 = never; 5 = always). The items were summed to have a single score of problematic use with higher scores indicating more serious problems $(\alpha=.88)$.

3.2.2.3. UPPS-P Impulsivity Scale - Short Version (UPPS-P). This version of the scale (Billieux et al., 2012) contains 20 items and assesses the impulsivity of the respondents on the basis of five dimensions: Negative Urgency (four items, e.g., "When I am upset I often act without thinking", $\alpha=.86$ ), Positive Urgency (four items, e.g., "When I am really excited, I tend not to think on the consequences of my actions.”, $\alpha=.77$ ), Sensation Seeking (four items, e.g., "I generally seek new and exciting experiences and activities", $\alpha=.76$ ), Lack of Premeditation (four items, e.g., "I usually think carefully before doing anything”, $\alpha=.81$ ), and Lack of Perseverance (four items, e.g., "I finish what I start.", $\alpha=.80$ ) with latter two factors being reverse scored. Participants answered on a four-point scale $(1=$ agree strongly; $4=$ disagree strongly).

\subsubsection{Statistical analysis}

The structural analyses were performed with Mplus 7.3, while the rest of the analyses were performed using SPSS 22 (IBM SPSS Inc., Chicago, Illinois). Regression analyses were chosen to investigate the effects of the predictor variables (i.e., Pokémon Go playing motivations and impulsivity) on the outcome variable (i.e., problematic Pokémon Go playing). Preliminary analyses were conducted to ensure that the assumptions of these analyses (i.e., normality and multicollinearity of the data) were not violated.

\subsection{Results}

\subsubsection{Descriptive statistics}


Similar to the results from the first sample, the highest mean scores were found in the Recreation and Nostalgia motives (see Table 3). Significant gender differences were observed in the Competition $(t(497)=5.28, p<.001)$ and Nostalgia motives $(t(508)=2.21, p=0.03)$ with men having higher scores, whereas female participants scored higher on the Recreation $(t(508)=$ 2.78, $p=.006)$ and Outdoor Activity $(t(508)=-1.95, p=.05)$ motives compared to male players. Furthermore, significant differences were found in the motivational levels of players regarding residence. Again, players who lived in county towns, other towns, and villages had higher scores on the Skill Development $(F(509)=5.79, p=.001)$ and Boredom $(F(509)=7.87, p<$ .001) motives than those who lived in the capital city as well as on the Competition $(F(509)=$ 3.57, $p=.01)$ and Outdoor Activity motives $(F(509)=2.92, p=.03)$. Similar to the results in the first data collection, it was found that highly educated players had significantly lower scores on the Social $(F(509)=4.77, p=.009)$, Skill Development $(F(509)=3.55, p=.03)$ and Fantasy motives $(F(509)=4.51, p=.01)$ as well as on the Nostalgia motive $(F(509)=4.59, p=.01)$. Age was significantly associated with four motivational factors: Social $(r=-.21, p<.001)$, Fantasy $(r=-.14, p=.002)$, Nostalgia $(r=-.39, p<.001)$, and Boredom $(r=-.25, p<.001)$. As in Study 1, Old Pokémon Fans again scored higher on the majority of Pokémon Go playing motivations, and the greatest mean score-difference was observed in the Nostalgia motivation $\left(M_{\text {Old Pokémon Fans }}=3.89, S D=1.16 ; M_{\text {New Pokémon Fans }}=2.51, S D=1.26\right)$. 
Table 2

Descriptive statistics and group comparisons in Sample $2(N=510)$

\begin{tabular}{|c|c|c|c|c|c|c|c|c|c|c|c|c|c|c|c|c|}
\hline & & & ider & & & Res & idence & & & & Education & & & Fan $\xi$ & groups & \\
\hline & $\begin{array}{l}\text { Total } \\
(\mathrm{N}=510)\end{array}$ & $\begin{array}{l}\text { Male } \\
(\mathrm{n}=285)\end{array}$ & $\begin{array}{l}\text { Female } \\
(n=225)\end{array}$ & $t$ & $\begin{array}{l}\text { Capital } \\
\text { city } \\
(n=175)\end{array}$ & $\begin{array}{l}\text { County } \\
\text { towns } \\
(n=58)\end{array}$ & $\begin{array}{l}\text { Other } \\
\text { towns } \\
(n=196)\end{array}$ & $\begin{array}{l}\text { Villages } \\
(\mathrm{n}=81)\end{array}$ & $F$ & $\begin{array}{l}\text { Higher } \\
\text { education } \\
(n=145)\end{array}$ & $\begin{array}{l}\text { High } \\
\text { school } \\
\text { degree } \\
(\mathrm{n}=317)\end{array}$ & $\begin{array}{l}\text { Primary } \\
\text { school } \\
\text { degree } \\
(n=48)\end{array}$ & $F$ & $\begin{array}{l}\text { Old } \\
\text { Pokémon } \\
\text { fans } \\
(\mathrm{n}=257)\end{array}$ & $\begin{array}{l}\text { New } \\
\text { Pokémon } \\
\text { fans } \\
(\mathrm{n}=187)\end{array}$ & $t$ \\
\hline $\begin{array}{l}\text { Frequency of } \\
\text { playing }\end{array}$ & $\begin{array}{l}12.05 \\
(13.79)\end{array}$ & $\begin{array}{l}13.10 \\
(14.52)\end{array}$ & $\begin{array}{l}10.74 \\
(12.73)\end{array}$ & 1.92 & $\begin{array}{l}11.97 \\
(13.00) \mathrm{a}\end{array}$ & $\begin{array}{l}12.02 \\
(13.13) \mathrm{a}\end{array}$ & $\begin{array}{l}12.60 \\
(15.94) \mathrm{a}\end{array}$ & $\begin{array}{l}10.94 \\
(10.04) a\end{array}$ & 0.28 & $\begin{array}{l}11.68 \\
(12.34) \mathrm{a}\end{array}$ & $\begin{array}{l}11.96 \\
(14.32) a\end{array}$ & $\begin{array}{l}13.83 \\
(14.62) a\end{array}$ & 0.45 & $\begin{array}{l}12.38 \\
(14.34)\end{array}$ & $\begin{array}{l}11.44 \\
(13.76)\end{array}$ & -0.69 \\
\hline Social & $\begin{array}{l}2.06 \\
(1.01)\end{array}$ & $\begin{array}{l}2.12 \\
(1.02)\end{array}$ & $\begin{array}{l}1.98 \\
(1.00)\end{array}$ & 1.52 & $\begin{array}{l}1.90 \\
(0.91) \mathrm{a}\end{array}$ & $\begin{array}{l}2.16 \\
(1.00) \mathrm{a}\end{array}$ & $\begin{array}{l}2.17 \\
(1.05) \mathrm{a}\end{array}$ & $\begin{array}{l}2.07 \\
\text { (1.10)a }\end{array}$ & 2.44 & $\begin{array}{l}1.88 \\
(0.91) a\end{array}$ & $\begin{array}{l}2.10 \\
(1.02) a b\end{array}$ & $\begin{array}{l}2.36 \\
(1.15) \mathrm{b}\end{array}$ & $4.77^{* *}$ & $\begin{array}{l}2.10 \\
(1.03)\end{array}$ & $\begin{array}{l}2.10 \\
(1.01)\end{array}$ & 0.01 \\
\hline Escape & $\begin{array}{l}1.84 \\
(1.00)\end{array}$ & $\begin{array}{l}1.80 \\
(0.95)\end{array}$ & $\begin{array}{l}1.90 \\
(1.06)\end{array}$ & -1.14 & $\begin{array}{l}1.76 \\
(0.94) a\end{array}$ & $\begin{array}{l}2.05 \\
(1.10) a\end{array}$ & $\begin{array}{l}1.79 \\
(0.95) a\end{array}$ & $\begin{array}{l}1.99 \\
(1.16) \mathrm{a}\end{array}$ & 1.97 & $\begin{array}{l}1.78 \\
(0.98) a\end{array}$ & $\begin{array}{l}1.86 \\
(1.02) \mathrm{a}\end{array}$ & $\begin{array}{l}1.89 \\
(0.97) a\end{array}$ & 0.40 & $\begin{array}{l}1.95 \\
(1.08)\end{array}$ & $\begin{array}{l}1.69 \\
(0.87)\end{array}$ & $-2.76^{* *}$ \\
\hline Competition & $\begin{array}{l}2.57 \\
(1.19)\end{array}$ & $\begin{array}{l}2.77 \\
(1.21)\end{array}$ & $\begin{array}{l}2.22 \\
(1.11)\end{array}$ & $5.28^{* * *}$ & $\begin{array}{l}2.32 \\
(1.09) a\end{array}$ & $\begin{array}{l}2.66 \\
(1.27) b\end{array}$ & $\begin{array}{l}2.56 \\
(1.19) \mathrm{b}\end{array}$ & $\begin{array}{l}2.81 \\
(1.28) b\end{array}$ & $3.57^{*}$ & $\begin{array}{l}2.39 \\
(1.16) a\end{array}$ & $\begin{array}{l}2.59 \\
(1.20) \mathrm{a}\end{array}$ & $\begin{array}{l}2.54 \\
(1.25) \mathrm{a}\end{array}$ & 1.41 & $\begin{array}{l}2.63 \\
(1.21)\end{array}$ & $\begin{array}{l}2.43 \\
(1.15)\end{array}$ & -1.71 \\
\hline Coping & $\begin{array}{l}2.27 \\
(0.97)\end{array}$ & $\begin{array}{l}2.21 \\
(0.97)\end{array}$ & $\begin{array}{l}2.34 \\
(0.96)\end{array}$ & -1.49 & $\begin{array}{l}2.19 \\
(0.93) a\end{array}$ & $\begin{array}{l}2.36 \\
(0.94) a\end{array}$ & $\begin{array}{l}2.23 \\
(0.95) a\end{array}$ & $\begin{array}{l}2.48 \\
(1.00) a\end{array}$ & 2.05 & $\begin{array}{l}2.20 \\
(0.93) a\end{array}$ & $\begin{array}{l}2.29 \\
(0.98) a\end{array}$ & $\begin{array}{l}2.33 \\
(0.97) a\end{array}$ & 0.50 & $\begin{array}{l}2.39 \\
(1.02)\end{array}$ & $\begin{array}{l}2.10 \\
(0.88)\end{array}$ & $-3.21^{* *}$ \\
\hline $\begin{array}{l}\text { Skill } \\
\text { Development }\end{array}$ & $\begin{array}{l}1.84 \\
(0.95)\end{array}$ & $\begin{array}{l}1.85 \\
(0.97)\end{array}$ & $\begin{array}{l}1.82 \\
(0.92)\end{array}$ & 0.29 & $\begin{array}{l}1.62 \\
(0.78) a\end{array}$ & $\begin{array}{l}1.95 \\
(0.94) a b\end{array}$ & $\begin{array}{l}1.90 \\
(1.00) b\end{array}$ & $\begin{array}{l}2.09 \\
(1.07) b\end{array}$ & $5.79^{* *}$ & $\begin{array}{l}1.68 \\
(0.85) a\end{array}$ & $\begin{array}{l}1.88 \\
(0.98) a b\end{array}$ & $\begin{array}{l}2.05 \\
(0.96) \mathrm{b}\end{array}$ & $3.55^{*}$ & $\begin{array}{l}1.97 \\
(1.02)\end{array}$ & $\begin{array}{l}1.70 \\
(0.81)\end{array}$ & $-3.12^{* *}$ \\
\hline Fantasy & $\begin{array}{l}1.88 \\
(1.04)\end{array}$ & $\begin{array}{l}1.93 \\
(1.06)\end{array}$ & $\begin{array}{l}1.81 \\
(1.00)\end{array}$ & 1.26 & $\begin{array}{l}1.73 \\
(0.90) a\end{array}$ & $\begin{array}{l}1.94 \\
(1.09) a\end{array}$ & $\begin{array}{l}1.89 \\
(1.06) \mathrm{a}\end{array}$ & $\begin{array}{l}2.10 \\
(1.18) \mathrm{a}\end{array}$ & 2.43 & $\begin{array}{l}1.72 \\
(0.90) a\end{array}$ & $\begin{array}{l}1.90 \\
\text { (1.07)ab }\end{array}$ & $\begin{array}{l}2.22 \\
(1.13) \mathrm{b}\end{array}$ & $4.51^{*}$ & $\begin{array}{l}2.05 \\
(1.10)\end{array}$ & $\begin{array}{l}1.75 \\
(0.96)\end{array}$ & $-3.05^{* *}$ \\
\hline Recreation & $\begin{array}{l}4.26 \\
(0.73)\end{array}$ & $\begin{array}{l}4.18 \\
(0.75)\end{array}$ & $\begin{array}{l}4.36 \\
(0.70)\end{array}$ & $-2.78^{* *}$ & $\begin{array}{l}4.31 \\
(0.69) a\end{array}$ & $\begin{array}{l}4.41 \\
(0.69) a\end{array}$ & $\begin{array}{l}4.16 \\
(0.77) \mathrm{a}\end{array}$ & $\begin{array}{l}4.26 \\
(0.72) \mathrm{a}\end{array}$ & 2.37 & $\begin{array}{l}4.23 \\
(0.93) a\end{array}$ & $\begin{array}{l}4.26 \\
(0.73) \mathrm{a}\end{array}$ & $\begin{array}{l}4.32 \\
(0.75) a\end{array}$ & 0.25 & $\begin{array}{l}4.34 \\
(0.70)\end{array}$ & $\begin{array}{l}4.13 \\
(0.76)\end{array}$ & $-3.12^{* *}$ \\
\hline
\end{tabular}




\begin{tabular}{|c|c|c|c|c|c|c|c|c|c|c|c|c|c|c|c|c|}
\hline $\begin{array}{l}\text { Outdoor } \\
\text { Activity }\end{array}$ & $\begin{array}{l}3.01 \\
(1.24)\end{array}$ & $\begin{array}{l}2.92 \\
(1.20)\end{array}$ & $\begin{array}{l}3.13 \\
(1.28)\end{array}$ & $-1.95^{*}$ & $\begin{array}{l}2.81 \\
(1.24) \mathrm{a}\end{array}$ & $\begin{array}{l}2.99 \\
(1.21) b\end{array}$ & $\begin{array}{l}3.09 \\
(1.23) b\end{array}$ & $\begin{array}{l}3.26 \\
(1.21) \mathrm{b}\end{array}$ & $2.92^{*}$ & $\begin{array}{l}3.05 \\
(1.27) \mathrm{a}\end{array}$ & $\begin{array}{l}3.00 \\
(1.24) \mathrm{a}\end{array}$ & $\begin{array}{l}3.00 \\
(1.10) a\end{array}$ & 0.08 & $\begin{array}{l}3.09 \\
(1.26)\end{array}$ & $\begin{array}{l}2.90 \\
(1.20)\end{array}$ & -1.60 \\
\hline Nostalgia & $\begin{array}{l}3.06 \\
(1.43)\end{array}$ & $\begin{array}{l}3.18 \\
(1.45)\end{array}$ & $\begin{array}{l}2.89 \\
(1.49)\end{array}$ & $2.21^{*}$ & $\begin{array}{l}2.86 \\
(1.49) a\end{array}$ & $\begin{array}{l}3.17 \\
(1.50) a\end{array}$ & $\begin{array}{l}3.07 \\
(1.48) a\end{array}$ & $\begin{array}{l}3.36 \\
(1.37) a\end{array}$ & 2.28 & $\begin{array}{l}2.74 \\
(1.47) \mathrm{a}\end{array}$ & $\begin{array}{l}3.18 \\
(1.45) \mathrm{b}\end{array}$ & $\begin{array}{l}3.17 \\
(1.50) a b\end{array}$ & $4.59^{*}$ & $\begin{array}{l}3.89 \\
(1.16)\end{array}$ & $\begin{array}{l}2.51 \\
(1.26)\end{array}$ & $-11.93^{* * *}$ \\
\hline Boredom & $\begin{array}{l}2.59 \\
(1.07)\end{array}$ & $\begin{array}{l}2.60 \\
(1.06)\end{array}$ & $\begin{array}{l}2.57 \\
(1.10)\end{array}$ & 0.24 & $\begin{array}{l}2.34 \\
(1.00) a\end{array}$ & $\begin{array}{l}2.57 \\
\text { (1.04)abc }\end{array}$ & $\begin{array}{l}2.63 \\
(1.08) \mathrm{b}\end{array}$ & $\begin{array}{l}3.02 \\
(1.13) \mathrm{C}\end{array}$ & $7.87^{* * *}$ & $\begin{array}{l}2.46 \\
(1.12) \mathrm{a}\end{array}$ & $\begin{array}{l}2.65 \\
(1.07) a\end{array}$ & $\begin{array}{l}2.56 \\
(0.96) a\end{array}$ & 1.59 & $\begin{array}{l}2.71 \\
(1.06)\end{array}$ & $\begin{array}{l}2.59 \\
(1.03)\end{array}$ & -1.14 \\
\hline
\end{tabular}

Notes. Different subscript letters (a, b, c) in the same row represent significant ( $<$.05) difference between the mean scores, whereas same subscript letters in the same row represent non-significant difference between the mean scores according to the post-hoc Tukey test of one-way ANOVA

${ }^{*} \mathrm{p}<.05 ;{ }^{* *} \mathrm{p}<.01 ;{ }^{* * *} \mathrm{p}<.001$ 


\subsubsection{Cross-validation of the factorial structure of the MOGQ-PG}

For the purposes of further confirmation of the factor structure and internal consistency, before assessing the associations between the central construct (i.e., motivations) and other related constructs (i.e., problematic use and impulsivity), the factor structure of the MOGQ-PG was examined. This examination further supported the adequacy of this scale $\left(\chi^{2}=1459.383\right.$; degrees of freedom $=584 ; \mathrm{p}<.001 ; \mathrm{CFI}=.965 ; \mathrm{TLI}=.960 ;$ RMSEA $=.054[.051-.058])$. Factor loadings ( $\lambda=.64$ to .99$)$, inter-factor correlations ( $r=.12$ to .86$)$ and internal consistency indices $(\alpha=.69$ to .94$)$ were similar to that of Study 1 (see Table 4 ).

\section{Table 4}

Parameter estimates, descriptive statistics and reliability indices for the Online Gaming Questionnaire-Pokémon Go extension (MOGQ-PG) on Sample $2(N=510)$

\begin{tabular}{|c|c|c|c|c|c|}
\hline \multirow{2}{*}{ I play Pokémon Go... } & \multirow{2}{*}{$\alpha$} & \multicolumn{3}{|c|}{ Descriptive statistics } & \multirow{2}{*}{$\begin{array}{r}\text { Factor } \\
\text { loadings }\end{array}$} \\
\hline & & Range & Mean & SD & \\
\hline Social & .86 & $1-5$ & 2.06 & 1.01 & \\
\hline 1. ... because I can get to know new people & & & & & .91 \\
\hline 10. ... because I can meet many different people & & & & & .95 \\
\hline 21. ... because it is a good social experience & & & & & .74 \\
\hline 32. ... because gaming gives me company & & & & & .91 \\
\hline Escape & .86 & $1-5$ & 1.84 & 1.00 & \\
\hline $\begin{array}{l}\text { 2. ... because gaming helps me to forget about daily } \\
\text { hassles }\end{array}$ & & & & & .83 \\
\hline 12. ... because it makes me forget real life & & & & & .85 \\
\hline 22. ... because gaming helps me escape reality & & & & & .91 \\
\hline 33. ... to forget about unpleasant things or offences & & & & & .87 \\
\hline Competition & .90 & $1-5$ & 2.57 & 1.19 & \\
\hline 4. ... because I enjoy competing with others & & & & & .85 \\
\hline 13. ... because I like to win & & & & & .87 \\
\hline $\begin{array}{l}23 . . . \text { because it is good to feel that I am better than } \\
\text { others }\end{array}$ & & & & & .88 \\
\hline
\end{tabular}


34. ... for the pleasure of defeating others

Coping

.80

$1-5 \quad 2.27$

0.97

6 . ... because gaming helps me get into a better

mood

15. ... because it helps me get rid of stress

25. ... because it helps me channel my aggression

.82

$35 . .$. because it reduces tension

.85

Skill development .87 $1-5$

1.84

0.95

7. ... because gaming sharpens my senses

17. ... because it improves my skills .83

26. ... because it improves my concentration .91

36. ... because it improves my coordination skills .85

Fantasy .82 $1-5$

1.88

1.04

8. ... because I can do things that I am unable to do or I am not allowed to do in real life

18. ... to feel as if I was somebody else .87

28. ... to be somebody else for a while

37. ... because I can be in another world .86

Recreation
.69 $1-5$

4.26

0.73

9. ... for recreation .80

19. ... because it is entertaining .78

30. ... because I enjoy gaming .74

Outdoor activity .91 $1-5$

3.01 1.24

11 . ... because it gets me moving .89

24. ... because I spend more time in the fresh air .88

29 . ... because it provides the daily dose of exercise .89

31 .... because I can get out of the house

Nostalgia .94 $1-5$ 3.06 1.43

5. ... because it reminds me of my childhood .80

16. ... it is nostalgic .94

27. ... it brings up old memories .90

Boredom .76 $1-5$ 2.59 1.07

3. ... at least I am not bored meanwhile

14. ... otherwise I would be bored

20. ... time goes faster .77

Note. $\alpha=$ Cronbach's alpha value; $\mathrm{SD}=$ standard deviation. The instruction and scoring was the same as in the case of Study 1. 


\subsubsection{Associations between Pokémon Go playing motivations, problematic use, and impulsivity}

Correlations between the examined variables can be seen in Table 5. They indicate relatively weak associations between motivational dimensions and the different aspects of impulsivity. In order to examine the associations between impulsivity in general and Pokémon Go playing motivations, a hierarchical regression analysis was carried out in which the predictor variables were three demographic variables (age, gender, level of education) in the first step, then in the second step the Pokémon Go motivational variables were inserted and the outcome variable was the composite score of the UPPS-P Impulsivity Scale. On the basis of the regression results, it can be seen that none of the Pokémon Go motivational variables were significantly related to impulsivity (see Table 6). According to the correlations in Table 5, escapism, competition, coping, skill development, and fantasy motivations were more strongly related to problematic gaming than the impulsivity dimensions. 
Table 5

Inter-correlations between the examined variables

\begin{tabular}{|c|c|c|c|c|c|c|c|c|c|c|c|c|c|c|c|c|}
\hline & (1) & (2) & (3) & (4) & (5) & (6) & (7) & (8) & (9) & $(10)$ & (11) & (12) & (13) & (14) & (15) & (16) \\
\hline (1) Social & - & & & & & & & & & & & & & & & \\
\hline (2) Escape & $.34^{* *}$ & - & & & & & & & & & & & & & & \\
\hline (3) Competition & $.31^{* *}$ & $.28^{* *}$ & - & & & & & & & & & & & & & \\
\hline (4) Coping & $.35^{* *}$ & $.70^{* *}$ & $.29^{* *}$ & - & & & & & & & & & & & & \\
\hline $\begin{array}{l}\text { (5) Skill } \\
\text { Development }\end{array}$ & $.44^{* *}$ & $.50^{* *}$ & $.34^{* *}$ & $.57^{* *}$ & - & & & & & & & & & & & \\
\hline (6) Fantasy & $.31^{* *}$ & $.64^{* *}$ & $.28^{* *}$ & $.53^{* *}$ & $.58^{* *}$ & - & & & & & & & & & & \\
\hline (7) Recreation & $.25^{* *}$ & $.24^{* *}$ & $.20^{* *}$ & $.41^{* *}$ & $.31^{* *}$ & $.24^{* *}$ & - & & & & & & & & & \\
\hline (8) Outdoor & $.36^{* *}$ & $.33^{* *}$ & $.15^{* *}$ & $.41^{* *}$ & $.43^{* *}$ & $.23^{* *}$ & $.31^{* *}$ & - & & & & & & & & \\
\hline (9) Nostalgia & $.21^{* *}$ & $.20^{* *}$ & $.10^{*}$ & $.24^{* *}$ & $.26^{* *}$ & $.35^{* *}$ & $.21^{* *}$ & $.15^{* *}$ & - & & & & & & & \\
\hline (10) Boredom & $.23^{* *}$ & $.35^{* *}$ & $.16^{* *}$ & $.33^{* *}$ & $.25^{* *}$ & $.29^{* *}$ & $.16^{* *}$ & $.25^{* *}$ & $.20^{* *}$ & - & & & & & & \\
\hline (11) Neg. Urgency & .08 & $.13^{* *}$ & $.13^{* *}$ & $.11^{*}$ & $.10^{*}$ & .08 & .02 & .04 & .05 & $.10^{*}$ & - & & & & & \\
\hline (12) Pos. Urgency & $.13^{* *}$ & $.15^{* *}$ & $.14^{* *}$ & $.17^{* *}$ & $.14^{* *}$ & $.13^{* *}$ & .05 & .03 & .06 & .07 & $.69^{* *}$ & - & & & & \\
\hline (13) Lack of Premed. & $.10^{*}$ & .08 & -.01 & .07 & .03 & .01 & -.03 & -.01 & -.03 & .01 & $.33^{* *}$ & $.31^{* *}$ & - & & & \\
\hline (14) Lack of Persev. & $.12^{* *}$ & $.13^{* *}$ & -.02 & $.11^{*}$ & .05 & .07 & -.01 & .07 & -.06 & .06 & $.14^{* *}$ & $.14^{* *}$ & $.48^{* *}$ & - & & \\
\hline (15) Sens. Seeking & $.18^{* *}$ & .02 & $.22^{* *}$ & .08 & $.20^{* *}$ & .09 & .02 & -.03 & .08 & .02 & $.30^{* *}$ & $.41^{* *}$ & -.04 & $-.16^{* *}$ & - & \\
\hline (16) Impulsivity & $.18^{* * *}$ & $.16^{* * *}$ & $.15^{* *}$ & $.15^{* *}$ & $.17^{* * *}$ & $.12^{*}$ & .02 & .03 & .04 & .08 & $.81^{* * *}$ & $.82^{* * *}$ & $.61^{* * *}$ & $.44^{* * *}$ & $.50^{* * *}$ & - \\
\hline (17) POGQ & $.31^{* *}$ & $.38^{* *}$ & $.34^{* *}$ & $.39^{* *}$ & $.38^{* *}$ & $.36^{* *}$ & $.18^{* *}$ & $.26^{* *}$ & .07 & $.20^{* *}$ & $.15^{* *}$ & $.17^{* *}$ & $.12^{* *}$ & $.17^{* *}$ & .09 & $.21^{* * *}$ \\
\hline
\end{tabular}

Note. Neg. Urgency = UPPS, Negative Urgency; Pos. Urgency = UPPS Positive Urgency; Lack of Premed. = UPPS Lack of Premeditation; Sens.

Seeking = UPPS Sensation Seeking; Impulsivity = All UPPS subscales; POGQ = Problematic Online Gaming Questionnaire;

${ }^{*} p<.05 ;{ }^{* *} p<.01 ;{ }^{* * *} p<.001$ 
Table 6

Regression model of impulsivity with demographic variables and Pokémon Go motivations as predictors

\begin{tabular}{|c|c|c|c|c|}
\hline & \multicolumn{2}{|c|}{ Unstandardized } & \multirow{2}{*}{$\begin{array}{c}\text { Standardized } \\
\beta\end{array}$} & \multirow[b]{2}{*}{$\mathrm{t}$} \\
\hline & B & Std. Error & & \\
\hline \multicolumn{5}{|l|}{ Step 1 (Adjusted $\mathrm{R}^{2}=.033$ ) } \\
\hline (Constant) & 2.55 & 0.10 & & 25.67 \\
\hline Gender & 0.02 & 0.04 & .02 & 0.54 \\
\hline Age & 0.07 & 0.01 & $-.13^{* *}$ & -2.88 \\
\hline Level of education & -0.06 & 0.02 & $-.13^{* *}$ & -2.82 \\
\hline \multicolumn{5}{|l|}{ Step 2 (Adjusted $\mathrm{R}^{2}=.067$ ) } \\
\hline (Constant) & 2.41 & 0.17 & & 14.54 \\
\hline Gender & 0.04 & 0.04 & .04 & 0.88 \\
\hline Age & -0.01 & 0.01 & $.12^{*}$ & -2.40 \\
\hline Level of education & -0.05 & 0.02 & $-.10^{*}$ & -2.30 \\
\hline MOGQ-PG Social & 0.04 & 0.02 & $.10^{\dagger}$ & 1.89 \\
\hline MOGQ-PG Escapism & 0.02 & 0.03 & .05 & 0.78 \\
\hline MOGQ-PG Competition & 0.03 & 0.02 & .08 & 1.61 \\
\hline MOGQ-PG Coping & 0.04 & 0.03 & $.11^{\dagger}$ & 1.70 \\
\hline MOGQ-PG Skill development & 0.04 & 0.03 & .08 & 1.31 \\
\hline MOGQ-PG Fantasy & -0.03 & 0.03 & -.06 & -0.94 \\
\hline
\end{tabular}




$\begin{array}{lllll}\text { MOGQ-PG Recreation } & -0.03 & 0.03 & -.06 & -1.13 \\ \text { MOGQ-PG Outdoor activity } & -0.03 & 0.02 & -.07 & 1.38 \\ \text { MOGQ-PG Nostalgia } & -0.02 & 0.02 & -.05 & -0.97 \\ \text { MOGQ-PG Boredom } & -0.01 & 0.02 & -.01 & -.19 \\ & & & & \\ \text { Note.UPPS-P = UPPS-P Impulsivity Scale; MOGQ = Motives for Online Gaming } \\ \text { Questionnaire } \\ { }^{\dagger} p<.10 ;{ }^{*} p<.05 ;{ }^{* *} p<.01 ;{ }^{* * *} p<.001 .\end{array}$

In the next step of the analyses, hierarchical regression analysis (see Table 7) was performed in which problematic Pokémon Go use was the outcome variable and impulsivity factors were entered in the first step, whereas Pokémon Go playing motivations were entered in the second step as predictors. The total explained variance of the first and the second model was $4.4 \%$ and $25.7 \%$, respectively. In the overall model, the strongest predictor was the Competition motivation $(\beta=.19, p<.001)$, followed by the Fantasy motivation $(\beta=.12, p<$ $.05)$ and Lack of Perseverance $(\beta=.09, p<.05)$, while other variables had tendentious or nonsignificant effect on problematic Pokémon Go playing.

Table 7

Regression model of Pokémon Go motivations, problematic gaming, and impulsivity

\begin{tabular}{lcccc}
\hline & \multicolumn{2}{l}{ Unstandardized } & \multicolumn{2}{c}{ Standardized } \\
\cline { 2 - 3 } & $\mathrm{B}$ & Std. Error & & $\mathrm{t}$ \\
\hline Step 1 (Adjusted $\left.\mathrm{R}^{2}=.044\right)$ & & & & \\
\hline (Constant) & 1 & 0.14 & & 6.97 \\
UPPS-P Negative urgency & 0.02 & 0.04 & .03 & 0.52
\end{tabular}




\begin{tabular}{|c|c|c|c|c|}
\hline UPPS-P Positive urgency & 0.08 & 0.05 & .10 & 1.56 \\
\hline UPPS-P Lack of premeditation & 0.01 & 0.05 & .01 & 0.22 \\
\hline UPPS-P Lack of perseverance & 0.16 & 0.05 & $.15^{* *}$ & 3.06 \\
\hline UPPS-P Sensation seeking & 0.05 & 0.04 & .06 & 1.22 \\
\hline \multicolumn{5}{|l|}{ Step 2 (Adjusted $\mathrm{R}^{2}=.257$ ) } \\
\hline (Constant) & 0.56 & 0.19 & & 2.93 \\
\hline UPPS-P Negative urgency & 0.01 & 0.04 & .02 & 0.36 \\
\hline UPPS-P Positive urgency & 0.04 & 0.05 & .05 & 0.85 \\
\hline UPPS-P Lack of premeditation & 0.03 & 0.04 & .03 & 0.73 \\
\hline UPPS-P Lack of perseverance & 0.09 & 0.05 & $.09 *$ & 2.00 \\
\hline UPPS-P Sensation seeking & -0.01 & 0.04 & -.01 & -0.28 \\
\hline MOGQ-PG Social & 0.05 & 0.03 & $.09 \dagger$ & 1.93 \\
\hline MOGQ-PG Escapism & 0.05 & 0.04 & .08 & 1.23 \\
\hline MOGQ-PG Competition & 0.10 & 0.02 & $.19 * * *$ & 4.55 \\
\hline MOGQ-PG Coping & 0.06 & 0.04 & $.10 \dagger$ & 1.68 \\
\hline MOGQ-PG Skill development & 0.06 & 0.04 & .09 & 1.62 \\
\hline MOGQ-PG Fantasy & 0.07 & 0.03 & $.12 *$ & 2.04 \\
\hline MOGQ-PG Recreation & -0.01 & 0.04 & -.01 & -0.23 \\
\hline MOGQ-PG Outdoor activity & 0.03 & 0.02 & .06 & 1.37 \\
\hline MOGQ-PG Nostalgia & -0.03 & 0.02 & $-.08 \dagger$ & -1.79 \\
\hline MOGQ-PG Boredom & 0.01 & 0.02 & .02 & 0.52 \\
\hline
\end{tabular}

Note.UPPS-P = UPPS-P Impulsivity Scale; MOGQ = Motives for Online Gaming Questionnaire $\dagger p<.10 ; * p<.05 ; * * p<.01 ; * * * p<.001$. 


\section{General discussion}

Pokémon Go is the first augmented reality game to attract millions of players worldwide within a few weeks after its release on Android and iOS devices. Indeed, Pokémon has emerged as the second most successful videogame-based franchise after the Mario Brothers (Boyes, 2007). The popularity of Pokémon Go raises the question as to what motives drive players to engage in this augmented reality game. The aim of the present study was to explore the motivations underlying the playing of Pokémon Go, building on the previously established online gaming motives alongside new Pokémon Go-specific motivational dimensions. Due to the comprehensive nature of the MOGQ (Demetrovics et al., 2011) providing a wide range of online gaming motives, this assessment instrument was used to explore the motivations of Pokémon Go players in addition to the new factors derived from the qualitative component of the study prior to survey administration.

Based on theoretical considerations and the qualitative data collected from Pokémon Go players, three further motivational factors were identified in addition to the existing dimensions of the MOGQ. In order to test the psychometric properties of the integration of the original MOGQ factors along with the new ones, confirmatory factor analysis was performed on the 10factor model of Pokémon Go gaming motivations, and results showed that all factors had good internal consistency and demonstrated adequate fit to the data. Therefore, the present study was able to identify, define, and confirm the factor structure of the more comprehensive scale of Pokémon Go playing motivations. In addition to the seven original factors of the MOGQ, three new factors were identified: Outdoor Activity, Nostalgia, and Boredom. These motivations based on empirical research also matched those listed in speculative populist articles on the reasons why Pokémon Go is so popular with players (e.g., Griffiths, 2016).

Similar to previous studies (e.g., Demetrovics et al., 2011; Király et al., 2015), the strongest motive for Pokémon Go players was recreation, which was one of the seven 
motivational dimensions of the original MOGQ. This factor refers to players' motivation to relax and enjoy the entertaining aspects of the game. Conversely, the lowest scores were observed in the case of skill development and escapism motives (similar to Király et al., 2015). Therefore, escaping from reality was not a strong motivation for the respondents to engage in this augmented reality game. Besides escapism, skill development had similarly low scores, reflecting that players had not been playing Pokémon Go primarily for developing their cognitive, visual, and/or other skills. However, Pokémon Go players scored high on the newly identified motivational dimensions, highlighting the importance of these factors in the understanding of the motives for playing this game.

Additionally, it was found that men consistently showed higher motivational levels for competing behaviors in Pokémon Go than women across the two studies. This result was consistent with those findings reported by Demetrovics et al. (2011). Furthermore, players who lived in the capital city had lower motivational levels in skill development and boredom compared to those who lived in towns or villages. This result may be explained by the limited opportunities for leisure activities there. Moreover, highly educated and older players were less motivated in several aspects of playing motives in both studies (e.g., social, fantasy, nostalgia, and boredom motivations).

Regarding the newly identified motives in the MOGQ-PG, the factor of Outdoor Activity comprised items emphasizing the positive effects of moving, walking out of the house, and breathing some outside fresh air when playing the game. Portable handheld devices are practical, and allow players to walk in the park, or travel by public transportation while seeking out Pokémon species to catch in the game. This is supported by the meta-analysis of Fanning, Mullen, and McAuley (2012) who found that mobile devices were effective in enhancing physical activities. The authors provided an overview of 11 studies on the use of mobile devices for maintaining physical health, and concluded that smartphone technology can promote 
physical health behaviors by monitoring users’ physical activity, and thus providing feedback for their physical health status, which facilitates further health efforts. Regarding this factor, gender difference was observed only in the second study, which was conducted after the Pokémon Go fever. This motive was relatively important for the players as it had the third highest mean score out of the 10 motivational factors in both studies.

Second, Nostalgia was an important motive for those who had been fans of Pokémon prior to the introduction of Pokémon Go. These players emphasized that Pokémon Go revived old memories of their childhood. Indeed, the animated television series building on the Pokémon franchise was very popular amongst Hungarian children at the age of 4-7 years in the early 2000s (Soromjai, 2000). At this time, the Pokémon series attracted millions of young viewers worldwide (Tobin, 2004). In line with this, the results of a recent survey indicated that 78\% of Pokémon Go players were between 18 and 34 years (Smith, 2016), explaining the importance of this source of motivation for this age cohort. Similar to Pokémon Go, nostalgia has been identified as a driving force in other types of games that also have a history (e.g., platform games such as Mario Brothers) (Sloan, 2014; Suominen, 2008). Moreover, the Nostalgia factor had the second highest mean score out of the other motivation factors in both studies.

Finally, Boredom was identified as the third new motivational factor related to Pokémon Go. This motivational dimension comprises items describing individuals who choose to play Pokémon Go in order to avoid being bored. In online gaming research, mainly qualitative studies have emphasized the importance of boredom as a source of playing motivation (e.g., Hussain \& Griffiths, 2009; Wan \& Chiou, 2006). Given that Pokémon Go is mostly played on mobile devices, this function of passing time during walking, or when they have nothing better to do is similar to the motives reported by Hjorth and Richardson (2009), who found that $80 \%$ of respondents preferred playing mobile games while they were traveling and in a state of 
boredom. In relation to demographic variables, no gender difference was found on this motive. Finally, the mean score of the Boredom factor was higher than the mean scores on six of the seven original motivational dimensions but lower than the scores of the Recreation, Nostalgia, and Outdoor Activity factors in both studies.

Similar to the inter-correlations of factors observed in the original seven motivational factor structure (Demetrovics et al., 2011), all factors in the new instrument were significantly related, and the pattern of associations were similar to the original relations. Considering the findings of Table 5, relatively strong correlations were found between Coping, Escapism, and Fantasy. According to a previous study (Király et al., 2015), these three motivational factors were the strongest predictors of problematic gaming (for an overview, see Kuss \& Griffiths, 2012). It is possible that in the case of Pokémon Go, these three factors may also be useful in assessing the motivational basis of problematic use.

According to the correlational results, the UPPS-P factors were weakly related to the MOGQ-PG motivational factors. The results supported the hypothesized expectations (based on Király et al., 2015) because escapism and competition were both positively related to the majority of the impulsivity factors. However, the correlation pattern did not show a clear-cut distinction between adaptive and less adaptive motivational dimensions such as Social, Coping, and Skill Development factors were similarly positively correlated with the majority of the assessed impulsivity dimensions. Furthermore, according to the regression results, no motivational variables were significantly related to the composite score of the UPPS impulsivity measure. In sum, impulsivity did not show a strong and consistent relationship pattern with the Pokémon Go motives because it was rather unrelated to these motives.

Regarding the personality background of problematic Pokémon Go use, the examined impulsivity dimensions were not found to be strong predictors. In the regression model, among the five UPPS-P factors (Billieux et al., 2012), only Lack of Perseverance showed a positive 
but weak relationship with problematic Pokémon Go use. Lack of Perseverance refers to giving up monotonous and boring tasks easily. According to the present results, playing Pokémon Go_-as an appealing and stimulating game-can become a problematic activity for those players who tend to give up boring tasks requiring perseverance.

Among the motivational variables, only Competition and Fantasy were weak predictors of the POGQ. These results partly supported the hypothesized expectations because competition was a predictor of problematic use. However, escapism was unrelated to problematic Pokémon Go use, despite the fact that prior research has identified escapism as the strongest predictor of problematic gaming in the case of MMORPG players (Király et al., 2015). According to previous research, players who displayed high level of psychiatric distress tend to use online gaming as a source of achievement. For instance, as Király et al. (2015) indicated, it is also possible that problematic players may replace "real life" competition achievement with competition within the game and achievement. However, alternative explanations are also possible.

For instance, in the MOGQ-PG, the wording of competition items includes resultorientation (e.g., “I like to win”), overcoming the opponent (e.g., “for the pleasure of defeating others”), feeling superior to others (e.g. "it is good to feel that I am better than others"), and one item refers to the enjoyment of competition. These items include both hypercompetitive and self-developmental attitudes (Ryckman, Hammer, Kaczor, \& Gold, 1990; 1996) with the dominance of hypercompetitive aspects. Further research should distinguish the role of these competitive attitudes in the competition motive of playing online and augmented reality games.

Although the present study has many strengths (such as the diverse online sample and the exhaustive statistical analyses), this study is not without limitations. First, the research was cross-sectional and survey-based that could result in possible biases (e.g., recall bias, social 
desirability bias). Longitudinal research would be beneficial because the popularity of Pokémon Go has begun to fall since its peak at the time of the first release. Furthermore, the present results need to be replicated in culturally diverse countries in order to draw a more solid conclusion about the relevance of the new motivational dimensions. The playing habits related to Pokémon Go and other AR games could also be examined among adolescents, and studying this cohort may also help to identify the potential health-related benefits of augmented reality games such as Pokémon Go. For instance, seeking out Pokémon species outside while engaged in walking activities could contribute to the mental and physical health of players. The temporal stability of motivational patterns could also be investigated in different stages of the popularity of this game and across different age groups. Finally, the results of the present research may not be generalizable to all AR games, for instance, to those games that do not have a longstanding historical background like the Pokémon franchise.

Despite the specific nature of the MOGQ-PG, the present study serves as the first step in the understanding of the underlying motivations of playing AR games. Future studies identifying specific motivational factors related to upcoming AR games may further contribute to the deeper understanding of gamers' motivations.

\section{Conclusion}

Despite the increasing popularity of AR games such as Pokémon Go, relatively little research attention has been paid to examining the underlying motivations of playing AR games. The present study explored the motivational patterns of playing Pokémon Go, by extending the motivational dimensions of an existing assessment tool, the MOGQ (Demetrovics et al., 2011) with three new motivational dimensions emerging (i.e., Outdoor Activity, Nostalgia, Boredom). This new measure, the MOGQ-PG, demonstrated good psychometric properties. Recreation, Outdoor Activity, Nostalgia, and Boredom were found to be the main motivations for players. 
Although the results suggest that the motivation of Pokémon Go players decreased in multiple aspects, the motives of competition and skill development as well as the need for recreation increased. Based on the relative importance of the uncovered new motivational factors, future studies should pay attention to these new gaming motives that appear with the widespread presence of geo-located smartphone applications. Among these potential motivations three were identified and assessed in the present study. If future AR games are similar to Pokémon Go, going outside, experiencing nostalgia, and avoiding boredom are also likely to be important motivational factors underlying engagement in these games.

\section{References}

Bandalos, D. L. (2014). Relative performance of categorical diagonally weighted least squares and robust maximum likelihood estimation. Structural Equation Modeling: A Multidisciplinary Journal, 21(1), 102-116. doi: 10.1080/10705511.2014.859510

Baranowski, T. (2016). Pokémon Go, go, go, gone? Games for Health Journal, 5(5). doi: 10.1089/g4h.2016.01055.tbp

Boyes, E. (2007). UK paper names top game franchises. GameSpot UK. Retrieved on August 26, 2016, from <http://www.gamespot.com/articles/uk-paper-names-top-gamefranchises/1100-6164012/>.

Brown, T. A. (2015). Confirmatory factor analysis for applied research (second edition). New York, NY: Guilford Press.

Chou, T. L., \&ChanLin, L. J. (2012). Augmented reality smartphone environment orientation application: a case study of the Fu-Jen University mobile campus touring system. Procedia-Social and Behavioral Sciences, 46, 410-416. doi: 10.1016/j.sbspro.2012.05.132 
Deci, E. L. \& Ryan, R. M (1985). Intrinsic motivation and self-determination in human behavior. New York: Plenum.

Deci, E. L., \& Ryan, R. M. (2000). The" what" and" why" of goal pursuits: Human needs and the self-determination of behavior. Psychological Inquiry, 11(4), 227-268. doi: 10.1207/S15327965PLI1104_01

Demetrovics, Z., Urbán, R., Nagygyörgy, K., Farkas, J., Zilahy, D., Mervó, B., Reindl, A., Ágoston, Cs., Kertész, A., \&Harmath, E. (2011). Why do you play? The development of the motives for online gaming questionnaire (MOGQ). Behavior Research Methods, 43(3), 814-825. doi: 10.3758/s13428-011-0091-y

Dunleavy, M., \& Dede, C. (2014). Augmented reality teaching and learning. In J. M. Spector, M. D. Merrill, J. Elen, \& M. J. Bishop (Eds.), Handbook of research on educational communications and technology (pp. 735-745). New York, NY: Springer. doi: 10.1007/978-1-4614-3185-5_59

Fahlman, S. A., Mercer-Lynn, K. B., Flora, D. B., \& Eastwood, J. D. (2011). Development and validation of the multidimensional state boredom scale. Assessment, 20(1), 68-85. doi: $10.1177 / 1073191111421303$

Fanning, J., Mullen, S. P., \&McAuley, E. (2012). Increasing physical activity with mobile devices: a meta-analysis. Journal of Medical Internet Research, 14(6), e161. doi: 10.2196/jmir.2171

Finney, S. J., \& DiStefano, C. (2006). Non-normal and categorical data in structural equation modeling. In G. R. Hancock and R. D. Mueller (Eds.), Structural Equation Modeling: A Second Course (pp. 269-314). Charlotte, NC: Information Age Publishing.

Gerrig, R. J., Zimbardo, P. G., Campbell, A. J., Cumming, S. R., \& Wilkes, F. J. (2011). Psychology and life. Australia: Pearson Higher Education 
Graham, M., Zook, M., \&Boulton, A. (2013). Augmented reality in urban places: Contested content and the duplicity of code. Transactions of the Institute of British Geographers, 38(3), 464-479. doi: 10.1111/j.1475-5661.2012.00539.x

Griffin, A. (2016). Pokémon Go beats porn on Google as game becomes easily one of the most popular ever. Independent. Retrieved on August 26, 2016, from < $\underline{\text { http://www.independent.co.uk/life-style/gadgets-and-tech/news/pokemon-go-porn- }}$ pornography-google-netherlands-uk-canada-a7134136.html>.

Griffiths, M.D. (2016). Test augmentation: 10 reasons why 'Pokemon Go’ is so appealing. July 22. Retrieved September 21, 2016, from: https://drmarkgriffiths.wordpress.com/2016/07/22/test-augmentation-10-reasons-whypokemon-go-is-so-appealing/

Hahn, J. (2012). Mobile augmented reality applications for library services. New Library World, 113(9/10), 429-438. doi: 10.1108/03074801211273902

Hjorth, L., \& Richardson, I. (2009). The waiting game: Complicating notions of (tele) presence and gendered distraction in casual mobile gaming. Australian Journal of Communication, 36(1), 23-35.

Hu, L., \&Bentler, P. M. (1999). Cutoff criteria for fit indexes in covariance structure analysis: Conventional criteria versus new alternatives. Structural Equation Modeling, 6(1), 155. doi: 10.1080/10705519909540118

Hussain, Z., \& Griffiths, M. D. (2009). The attitudes, feelings, and experiences of online gamers: a qualitative analysis. CyberPsychology \& Behavior, 12(6), 747-753. doi: 10.1089/cpb.2009.0059

Király, O., Nagygyörgy, K., Griffiths, M. D., \&Demetrovics, Zs. (2014). Problematic online gaming. In K. P. Rosenberg \& L. C. Feder (Eds.), Behavioral addictions: Criteria, 
evidence, and treatment(pp. 61-97). London, UK: Elsevier. doi: 10.1016/B978-0-12407724-9.00004-5

Király, O., Urbán, R., Griffiths, M. D., Ágoston, C., Nagygyörgy, K., Kökönyei, G., \&Demetrovics, Z. (2015). The mediating effect of gaming motivation between psychiatric symptoms and problematic online gaming: An online survey. Journal of Medical Internet Research, 17(4), e88. doi: 10.2196/jmir.3515

Kuss, D. J., \& Griffiths, M. D. (2012). Internet gaming addiction: A systematic review of empirical research. International Journal of Mental Health and Addiction,10(2), 278296. doi: 10.1007/s11469-011-9318-5

Lafrenière, M. A. K., Verner-Filion, J., \& Vallerand, R. J. (2012). Development and validation of the Gaming Motivation Scale (GAMS). Personality and Individual Differences, 53(7), 827-831. doi: 10.1016/j.paid.2012.06.013

Liau, A. K., Neo, E. C., Gentile, D. A., Choo, H., Sim, T., Li, D., \&Khoo, A. (2015). Impulsivity, self-regulation, and pathological video gaming among youth: Testing a mediation model. Asia Pacific Journal of Public Health, 27(2), NP2188-NP2196.

Mottram, A. J., \& Fleming, M. J. (2009). Extraversion, impulsivity, and online group membership as predictors of problematic Internet use. CyberPsychology \& Behavior, 12(3), 319-321. doi:10.1089/cpb.2007.0170.

Nunnally, J. C. (1978). Psychometric theory (2 $\left.{ }^{\text {nd }} e d.\right)$. New York: McGraw-Hill.

Nuyens, F., Deleuze, J., Maurage, P., Griffiths, M. D., Kuss, D. J., \& Billieux, J. (2016). Impulsivity in multiplayer online battle arena gamers: Preliminary results on experimental and self-report measures. Journal of Behavioral Addictions, 5(2), 351356. doi: $10.1556 / 2006.5 .2016 .028$

Rhemtulla, M., Brosseau-Liard, P. E., \& Savalei, V. (2012). When can categorical variables be treated as continuous? A comparison of robust continuous and categorical SEM 
estimation methods under suboptimal conditions. Psychological Methods, 17(3), 354373. doi: $10.1037 / \mathrm{a} 0029315$

Ryckman, R. M., Hammer, M., Kaczor, L. M. \& Gold, J. A. (1990). Construction of a Hypercompetitive Attitude Scale. Journal of Personality Assessment, 55(3/4), 630-639. doi: 10.1080/00223891.1990.9674097

Ryckman, R. M., Hammer, M., Kaczor, L. M. \& Gold, J. A. (1996). Construction of a Personal Development Competitive Attitude Scale. Journal of Personality Assessment, 66(2), 374. doi: 10.1207/s15327752jpa6602_15

Sloan, R. J. (2015). Videogames as remediated memories: commodified nostalgia and hyperreality in Far Cry 3: Blood Dragon and Gone Home. Games and Culture, 10(6), 525-550. doi: 10.1177/1555412014565641

Smith, C. (2016). Hot Game: Amazing Pokémon Go Statistics. DMR. Retrieved on August 26, 2016, from < $\underline{\text { http://expandedramblings.com/index.php/pokemon-go-statistics/> }}$.

Somorjai, L. (2000). Gyerekek víziója [Vision of children]. Hetek [Weeks], 4(41). Retrieved on August 26, 2016, from < $\underline{\text { http://epa.oszk.hu/00800/00804/00134/8707.html>. }}$

Suominen, J. (2008). The past as the future? Nostalgia and retrogaming in digital culture. Fibreculture, 11.RetrievedAugust 26, 2016, from:

$<\underline{\text { http://www.journal.fibreculture.org/issue11/issue11_suominen_print.html }>}$

Tobin, J. (Ed.). (2004). Pikachu's global adventure: The rise and fall of Pokémon. Durham, NC: Duke University Press.

Wan, C. S., \& Chiou, W. B. (2006). Why are adolescents addicted to online gaming? An interview study in Taiwan. CyberPsychology \& Behavior, 9(6), 762-766. doi: 10.1089/cpb.2006.9.762 
Wu, H. K., Lee, S. W. Y., Chang, H. Y., \& Liang, J. C. (2013). Current status, opportunities and challenges of augmented reality in education. Computers \& Education, 62, 41-49. doi: 10.1016/j.compedu.2012.10.024

Yee, N. (2006). Motivations for play in online games. CyberPsychology \& Behavior, 9(6), 772775. doi: 10.1089/cpb.2006.9.772

Yee, N., Ducheneaut, N., \& Nelson, L. (2012). Online gaming motivations scale: development and validation. In Proceedings of the SIGCHI Conference on Human Factors in Computing Systems (pp. 2803-2806). New York, NY: ACM. doi: $10.1145 / 2207676.2208681$

Yovcheva, Z., Buhalis, D., \& Gatzidis, C. (2012). Overview of smartphone augmented reality applications for tourism. e-Review of Tourism Research (eRTR), 10(2), 63-66. 